\title{
DIRECT BINDING OF RADIOIODINATED HUMAN CHORIONIC GONADOTROPHIN TO FROZEN SECTIONS OF RAT TESTIS
}

\author{
A. DAL LAGO, M. T. ROLANDI, M. BORTOLUSSI \\ AND S. GALLI \\ Department of Human Anatomy, University of Padua, \\ Via A. Gabelli 37, 35100-Padova, Italy
}

(Received 23rd fuly 1974)

Most published work on the binding of gonadotrophins to testicular tissue has been based on a biochemical approach and whole organs, homogenates or subcellular fractions have been used. Some studies have been concluded on interstitial tissue and/or seminiferous tubules separated from each other by microdissection after the method of Christensen \& Mason (1965). Binding of radioiodinated HCG to specific receptors of the interstitial cells as a first step in the chain of events leading to steroidogenesis has been demonstrated (Catt, Tsuruhara \& Dufau, 1972; Catt, Watanabe \& Dufau, 1972).

Few morphological studies aiming at the histological or cytological localization of the binding of the gonadotrophins in the testis have been published to date. Labelled or unlabelled gonadotrophins have been injected in vivo and traced thereafter by various methods and techniques: autoradiography (de Kretser, Catt, Burger \& Smith, 1969), immunofluorescence and histochemistry (Mancini, Castro \& Seiguer, 1966; Castro, Alonso \& Mancini, 1972) and electron microscopy (Castro, Seiguer \& Mancini, 1970). Unfortunately, knowledge of the metabolic events concerning injected hormones, especially labelled ones, is such that there is still doubt whether the localized substance is the original hormone or a metabolite and whether the localized uptake of the hormone by some tissue component is really the consequence of a specific hormone-receptor binding or of some other factors.

The following report presents the results that we have obtained using a method in which radioiodinated HCG was directly bound to frozen sections of rat testis in an attempt to avoid the intricacies of the experiments in vivo and approximate to the relative simplicity and precision of biochemical studies in vitro. A similar approach has been followed for the ovary (Midgley, 1973).

Frozen sections of testes from adult Wistar rats were obtained by direct immersion of small pieces $(3$ to $4 \mathrm{~mm})$ of tissue in liquid nitrogen $\left(-195^{\circ} \mathrm{C}\right)$ and sectioning at $7 \mu \mathrm{m}$ in a cryostat at $-20^{\circ} \mathrm{C}$. Cut sections were attached to glass slides prewarmed at $37^{\circ} \mathrm{C}$, left to dry at this temperature for $1 \mathrm{hr}$ on a thermostatically controlled warm stage and were then kept in a desiccator at 0 to $4^{\circ} \mathrm{C}$ until a sufficient number had been collected for further processing.

For binding study, a highly purified preparation of HCG, with a biological activity of 12,000 to 18,000 i.u. and mol. wt $\sim 47,000$ (Serono Immunochemi- 
cals, Rome), was used. The [ $\left.{ }^{125} \mathrm{I}\right] \mathrm{HCG}$ was labelled by the chloramine-T method (Greenwood, Hunter \& Glover, 1963), with a resulting specific radioactivity of $\sim 100 \mu \mathrm{Ci} / \mu \mathrm{g}$ (Serono Immunochemicals, Rome).

The following binding schedule was used. Each section, previously encircled by a wax ring, received an application of $50 \mu \mathrm{l}\left[{ }^{125} \mathrm{I}\right] \mathrm{HCG}(1 \mathrm{ng} / \mathrm{ml}$ in phosphate-buffered saline (PBS), pH 7.4). For the competition test on parallel sections, $50 \mu \mathrm{l}\left[{ }^{125} \mathrm{I}\right] \mathrm{HCG}(1 \mathrm{ng} / \mathrm{ml})+$ unlabelled HCG $(1 \mu \mathrm{g} / \mathrm{ml})$ were applied. The sections were incubated at $37^{\circ} \mathrm{C}$ for $1 \mathrm{hr}$ in a humidified chamber to prevent evaporation, and were then washed with three changes of PBS cooled to 0 to $4^{\circ} \mathrm{C}$. Washings were carried out at 5-min intervals, and constant horizontal shaking was effected between each change. The sections were post-fixed in absolute ethanol for $10 \mathrm{~min}$ and were finally washed with distilled water.

For autoradiography, the sections were coated with Kodak NTB-2 liquid dipping emulsion and exposed for 2 weeks at 0 to $4^{\circ} \mathrm{C}$. Developing was carried out at the same time for all the sections which were eventually stained with haematoxylin and eosin or other routine stains.

The results of the freezing method were considered satisfactory from the morphological point of view (Pl. 1, Fig. 1). Poorer results were obtained with other methods tried, i.e. slow freezing to $-20^{\circ} \mathrm{C}$ in the cryostat, snap freezing with decompressed $\mathrm{CO}_{2}\left(\sim-60^{\circ} \mathrm{C}\right)$, graded freezing to $-195^{\circ} \mathrm{C}$ using three steps inside a Dewar flask containing liquid $\mathrm{N}_{2}$, rapid freezing in isopentane cooled with liquid $\mathrm{N}_{2}\left(\sim-165^{\circ} \mathrm{C}\right)$. The peculiar difficulties encountered in subjecting testicular tissue to freezing procedures are probably due to the high water content of the tissue and crystal formation.

The sections obtained stained easily with all common dyes, with or without fixation, except with the periodic acid-Schiff method, often used to determine the spermatogenic stages of the seminiferous epithelium (Leblond \& Clermont, 1952). In all unfixed frozen sections, the acrosomal caps appeared as clear empty spaces: their negative image was helpful, however, in determining the stage of development.

A serious difficulty arose when it was found that the unfixed frozen sections were poorly able to withstand the incubation and washing procedures, partly losing their cellular components to the surrounding fluids, despite attempts to get the sections to adhere more closely by means of various solutions of gelatin and egg albumin applied to the slides. Fixation of the sections with a variety of

\section{EXPLANATION OF PLATE 1}

Fig. 1. Frozen unfixed section of rat testis, stained with haematoxylin and eosin. Interstitial cells, Sertoli cells nuclei, spermatocytes and spermatids are clearly identified. Arrows point to negative images of acrosomal caps. $\times 400$.

FIG. 2. Unstained autoradiography of a frozen section of rat testis fixed in $10 \%$ formalin. The section was incubated with $\left.{ }^{125} \mathrm{I}\right] \mathrm{HCG}$. The interstitial tissue appears heavily labelled by the autoradiographic reaction. $\times 100$.

FIG. 3. A section of rat testis treated in the same way as that shown in Fig. 2, after staining with haematoxylin and eosin, to show the relative density of autoradiographic grains in the interstitial tissue and seminiferous tubules. $\times 250$.

Fig. 4. High magnification detail of a section of rat testis treated in the same way as that shown in Fig. 3. The autoradiographic grains are significantly limited to the interstitial cells and show a prevalent cytoplasmic localization. The wall of the small artery is practically unmarked. $\times 800$. 


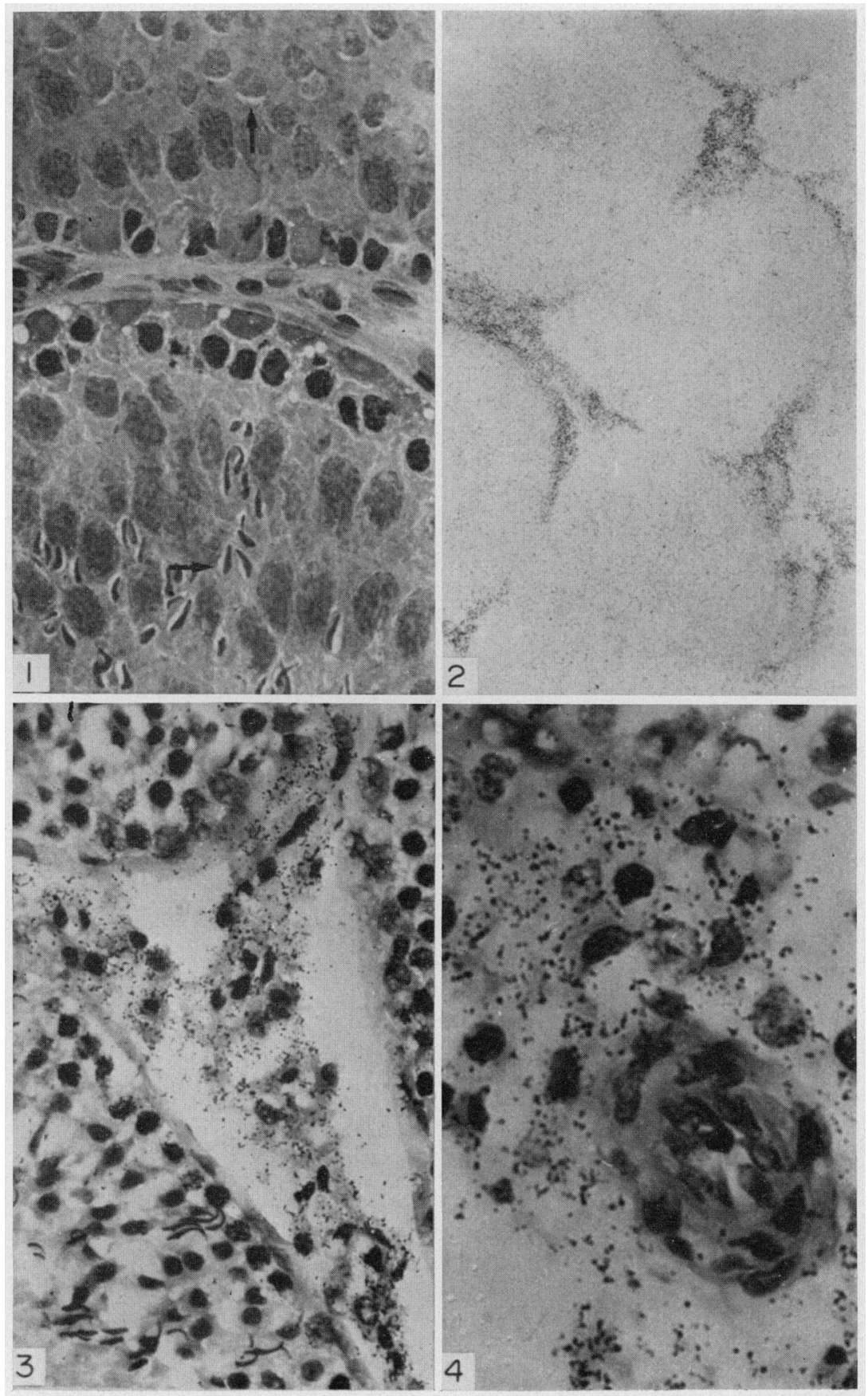

(Facing p. 124) 
fixatives before the incubation procedures largely or completely prevented such a cellular loss but, of all the fixatives tested, only $10 \%$ formalin (in $\mathrm{PBS}, \mathrm{pH} 7.4$ ) and newly formed formaldehyde from $4 \%$ paraformaldehyde (in PBS, $\mathrm{pH} 7.4$ ) satisfactorily preserved the ability of interstitial tissue to bind the $\left[{ }^{125} \mathrm{I}\right] \mathrm{HCG}$ selectively and specifically. The fixatives which were tried with negative results were: absolute ethanol, pure acetone, $2.5 \%$ acetic acid in water, a saturated solution of picric acid in water, $2.5 \%$ potassium dichromate in water, $1 \%$ osmium tetroxide in $\mathrm{PBS}, \mathrm{pH} 7.4,0.6 \%$ potassium permanganate in $\mathrm{PBS}, \mathrm{pH}$ $7 \cdot 4$, and $1 \%$ and $3 \%$ glutaraldehyde in $\mathrm{PBS}, \mathrm{pH} \mathrm{7.4}$. The concentrations of the fixatives were those commonly used in the fixation methods for light and electron microscopy.

Fixation with formalin was performed at 0 to $4^{\circ} \mathrm{C}$ for short periods of time, i.e. $30 \mathrm{~min}$ for the small pieces of testis and up to $10 \mathrm{~min}$ for the sections. This was followed by thoroughly washing the tissue in repeated changes of PBS.

The results obtained are illustrated in Pl. 1, Figs 2, 3 and 4. At the concentration used $(1 \mathrm{ng} / \mathrm{ml})$, selective binding of $\left[{ }^{125} \mathrm{I}\right] \mathrm{HCG}$ to the interstitial cells must be due to high-affinity active binding sites in these cells. The specificity of the reaction was always checked by competition tests with added excess of unlabelled HCG, which largely inhibited the $\left[{ }^{125}\right.$ I]HCG uptake by the interstitial cells.

The behaviour of the binding sites after treatment with the various fixatives used suggests that there should be substantial differences from those sites responsible for the antigen-antibody reaction, which was unimpaired after the various methods of fixation (Nairn, 1969) that were tried with negative results.

The binding of hormones to tissue sections should open up new possibilities for the study and analysis of binding phenomena in target organs in normal, experimental and pathological cases. One of the main advantages of the technique is its possible use for human biopsy and surgical specimens.

This work was supported in part by Grant No. CT74.00149.04 of the National Research Council of Italy. The authors are indebted to Mr G. Carlesso for his skilful technical assistance.

\section{REFERENCES}

Gastro, A. E., Alonso, A. \& Mancini, R. E. (1972) Localization of follicle stimulating and luteinizing hormones in the rat testis using immunohistological tests. F. Endocr. 52, 129-136.

Castro, A. E., Seiguer, A. C. \& Mancini, R. E. (1970) Electron microscopic study of the localization of labeled gonadotropins in the Sertoli and Leydig cells of the rat testis. Proc. Soc. exp. Biol. Med. 133, 582-586.

Gatt, K. J., Tsuruhara, T. \& Dufau, M. L. (1972) Gonadotrophin binding sites of the rat testis. Biochim. biophys. Acta, 279, 194-201.

Catt, K. J., Watanabe, K. \& Dufau, M. L. (1972) Cyclic AMP released by rat testis during gonadotrophin stimulation in vitro. Nature, Lond. 239, 280-281.

Ghristensen, A. K. \& Mason, M. R. (1965) Comparative ability of seminiferous tubules and interstitial tissue of rat testes to synthesize androgens from progesterone- $4-{ }^{14} \mathrm{C}$ in vitro. Endocrinology, 76, 646-656.

de Kretser, D. M., Catt, K. J., Burger, H. G. \& Smith, G. C. (1969) Radioautographic studies on the localization of ${ }^{125}$ I-labelled human luteinizing and growth hormones in immature male rats. 7. Endocr. 43, 105-111.

Greenwood, F. C., Hunter, W. M. \& Glover, J. S. (1963) The preparation of ${ }^{131}$ I-labelled human growth hormone of high specific radioactivity. Biochem. $7.89,114-123$. 
Leblond, C. P. \& Clermont, Y. (1952) Definition of the stages of the cycle of the seminiferous epithelium in the rat. Ann. N.Y. Acad. Sci. 55, 548-573.

Mancini, R. E., Castro, A. E. \& Seiguer, A. C. (1966) Histologic localization of follicle stimulating and luteinizing hormones in the rat testis. F. Histochem. Cytochem. 15, 516-525.

MIDGLeY, A. R., JR (1973) Autoradiographic analysis of gonadotropin binding to rat ovarian tissue sections. In Receptors for Reproductive Hormones, pp. 365-378. Eds. B. W. O'Malley and A. R. Means. Plenum Press, New York and London.

Nairv, R. C. (1969) Fluorescent Protein Tracing, 3rd edn, p. 125. Livingstone, Edinburgh and London. 